\title{
Penerimaan Peserta Didik Baru Secara Daring Di Masa Pandemi Covid-19 Pada Smpit Tambun Islamic School
}

\author{
Verra Sofica $^{1}$, Tasha Samira Febiola ${ }^{2}$, Minda Septiani ${ }^{3}$, Rahayu Ningsih ${ }^{4}$ \\ ${ }^{1}$ Sekolah Tinggi Manajemen Informatika dan Komputer Nusa Mandiri \\ e-mail: ${ }^{1}$ verra.vsc@ nusamandiri.ac.id \\ 2,3,4 Universitas Bina Sarana Informatika \\ e-mail: ${ }^{2}$ tasha.samira16@gmail.com, ${ }^{3}$ minda.mdt@bsi.ac.id, ${ }^{4}$ rahayu.ryh@bsi.ac.id

\begin{tabular}{ccc}
\hline Diterima & Direvisi & Disetujui \\
$08-10-2020$ & $09-11-2020$ & $15-12-2020$ \\
\hline
\end{tabular}

\begin{abstract}
Abstrak - Indonesia masih berjuang di tengah pandemi Covid-19 yang jumlah penularannya semakin menunjukkan peningkatan. Dunia pendidikan juga memerlukan perhatian khusus untuk terus berupaya menghentikan penyebaran Covid-19 dengan melaksanakan kegiatan pembelajaran dari rumah (BDR) dan meniadakan Ujian Nasional (UN) 2020. Kegiatan yang tidak kalah penting adalah penerimaan peserta didik baru (PPDB) tahun 2020 yang juga harus disesuaikan dengan kondisi pandemi saat ini. Kegiatan penerimaan peserta didik baru umumnya orang tua dan siswa datang langsung ke sekolah yang dituju. Disinilah yang menjadi permasalahan penelitian ini yaitu pada kondisi pandemi Covid-19 hal tersebut tidak dapat dilakukan karena dengan berkerumun di sekolah dapat menambah tingkat penularan virus Covid-19. Berdasarkan permasalahan di atas maka perlu dibuatkan sebuah website penerimaan peserta didik baru mulai dari proses daftar, seleksi dan hasil pengumuman dapat diakses dari rumah sehingga orang tua dan siswa tidak perlu datang ke sekolah. Selain itu website ini sebagai bentuk interaksi antara pihak sekolah dengan orang tua calon siswa. Web penerimaan peserta didik baru secara daring ini dibuat dengan metode pengembangan waterfall, serta menggunakan Bahasa Pemrograman PHP dan MySQL, sehingga tampilan situs menjadi lebih interaktif dan memberikan kemudahan bagi server untuk mengolah data dan informasi baru dengan cepat pada penerimaan peserta didik baru.
\end{abstract}

Kata Kunci: Penerimaan Peserta Didik Baru, Online

Abstarct - Indonesia is still struggling in the midst of the Covid-19 pandemic, where the number of infections is increasingly showing. The world of education also needs special attention to continue to strive to stop the spread of Covid-19 by carrying out learning activities from home (BDR) and eliminating the 2020 National Examination $(U N)$. Activities that are no less important are the admission of new students (PPDB) in 2020 which must also adapted to the current pandemic conditions. The activity of admitting new students is generally parents and students who come directly to the intended school. This is where the problem of this research is that in the conditions of the Covid-19 pandemic this cannot be done because crowding at school can increase the rate of transmission of the Covid-19 virus. Based on the above problems, it is necessary to make a new student admission website starting from the list process, selection and announcement results that can be accessed from home so that parents and students do not need to come to school. In addition, this website is a form of interaction between the school and the parents of prospective students. The web for accepting new students online is made with the waterfall development method, and uses the PHP and MySQL programming languages, so that the appearance of the site becomes more interactive and makes it easy for servers to process data and new information quickly on acceptance of new students.

Keywords: Admission of New Students, online

\section{PENDAHULUAN}

PPDB (Penerimaan Peserta Didik Baru) merupakan program yang dicanangkan setiap sekolah. Banyak cara melakukan program PPDB baik terjun langsung ke lapangan (sosialisasi), publikasi media cetak, dan publikasi secara online. Setiap tahuan kita selalu disuguhi dengan banner, spanduk, pamflet, dan stiker promosi setiap sekolah. Tujuannya adalah mencari siswa dan mempromoskan sekolah (Subbeh, 2018).

Menurut (PP, 2010) Pelaksanaan penerimaan peserta didik baru (PPDB) secara umum mendasarkan pada Peraturan Pemerintah Nomor 17 Tahun 2010 tentang Pengelolaan dan Penyelenggaraan Pendidikan. Produk hukum tersebut 
mengatur penerimaan peserta didik mulai dari tingkat usia dini, SD, SMP, SMA, hingga tingkat perguruan tinggi.

Penerimaan siswa baru merupakan gerbang awal yang harus dilalui peserta didik dan sekolah dalam penyaringan objek-objek pendidikan. Peristiwa penting bagi suatu sekolah, karena peristiwa ini merupakan titik awal yang menentukan kelancaran tugas suatu sekolah. Kesalahan dalam penerimaan siswa baru dapat menentukan sukses tidaknya usaha pendidikan disekolah yang bersangkutan.

Proses penerimaan peserta didik baru tahun ajaran 2020/2021 harus tetap berjalan di tengah pandemi Covid-19. Kegiatan yang semula dilakukan secara langsung oleh orang tua dan calon siswa ke sekolah yang dituju saat ini tidak dapat dilakukan dikarenakan dapat menyebabkan kerumunan dan membuka cluster baru penyebaran Covid-19.

Salah satu upaya untuk menghentikan penyebaran Covid-19 dengan mengganti sistem penerimaan peserta didik baru secara konvensional menjadi secara daring. Sehingga orang tua dapat mengakses segala informasi tentang sekolah yang cukup dari rumah.

Penelitian sebelumnya dilakukan oleh (Muslih \& Purnama, 2013) menyimpulkan bahwa Pengembangan melalui SMS gateway ini dipilih karena sesuai dengan kebutuhan penyampaian informasi yang cepat dan tepat sasaran yaitu calon siswa atau orang tua calon siswa. Pengembangan meliputi single SMS, broadcast SMS dan auto reply.

Penelitian selanjutnya dilakukan oleh (Kusuma, 2016) menyimpulkan bahwa diperlukan strategi perancanaan dan pemasaran dalam penerimaan peserta didik baru.

Permasalahan pada penelitian ini diantaranya:

1. Kegiatan PPDB secara konvensional atau datang langsung ke sekolah dapat menjadi cluster baru penyebaran virus Covid-19. 2. Sulitnya informasi PPDB yang dibuthkan orang tua terkait sekolah yang dituju.

Kumpulan halaman yang berisi informasi data digital baik berupa teks, gambar, animasi, suara, dan video atau gabungan dari semuanya yang disediakan melalui jalur koneksi internet. Sehingga dapat diakses dan dilihat oleh semua orang diseluruh dunia (Abdulloh, 2018).

Menurut (Rerung, 2018) "HTML adalah singkatan dari HyperText Markup Language. Disebut hypertext karena di dalam HTML sebuah text biasa dapat berfungsi lain, kita dapat membuatnya menjadi link yang dapat berpindah dari satu halaman ke halaman lainnya hanya dengan meng-klik text tersebut."

Menurut (Rerung, 2018) adalah singkatan dari "PHP : Hypertext Prepocessor", yaitu pemrograman yang digunakan secara luas untuk penanganan pembuatan dan pengembangan sebuah situs web, mulai dari halaman web yang sederhana sampai aplikasi komplek yang membutuhkan koneksi ke database.

Menurut (Supono \& Putratama, 2016) "Basis data (atau database) adalah kumpulan informasi yang disimpan didalam komputer secara sistematik sehingga dapat diperiksa menggunakan suatu program komputer untuk memperoleh informasi dari basis data tersebut".

(Madcoms, 2013) MySQL adalah salah satu jenis database server yang sangat terkenal. MySQL menggunakan bahasa SQL untuk mengakses database-nya. MySQL tersedia untuk beberapa platform, diantaranya adalah untuk versi windows dan versi linux. Sistem Database MySQL mendukung fitur seperti multithreaded, multi-user dan SQL Database Managemen System (DBMS). Database ini dibuat untuk keperluan sistem database yang cepat, handal, dan mudah digunakan.

PPDB (Penerimaan Peserta Didik Baru ) merupakan program yang dicanangkan setiap sekolah. Banyak cara melakukan program PPDB baik terjun langsung ke lapangan (sosialisasi), publikasi media cetak, dan publikasi secara online. Setiap tahuan kita selalu disuguhi dengan banner, spanduk, pamflet, dan stiker promosi setiap sekolah. Tujuannya adalah mencari siswa dan mempromoskan sekolah (Subbeh, 2018).

Daring atau online dalam jaringan adalah terjemahan dari istilah online yang bermakna tersambung ke dalam jaringan komputer. Secara umum daring atau online menunjukan keadaan terhubung (Kemenristekdikti, 2017). Dalam KBBI (Kamus Besar Bahasa Indonesia) daring merupakan kependekan dari kata dalam jaringan. Secara tidak langsung Online juga dapat diartikan sebagai suatu keadaan komputer yang dapat saling bertukar informasi karena sudah terhubung.

Analisis dan Desain Sistem UML (Unified Modelling Language)merupakan bahasa standar untuk membuat rancangan software untuk menggambarkan dan membangun dokumen artifak dari software intensive system (Booch, 2005).

\section{METODE PENELITIAN}

Metode penelitian pada penelitian ini menggunakan metode waterfall. Berikut tahapan pada metode waterfall. 1. Analisa Kebutuhan Perangkat Lunak dilakukan dengan mengumpulkan data yang dibutuhkan oleh admin pada tingkatan sistem dengan konsep, seperti kebutuhan data siswa, membuat pendaftaran untuk calon siswa baru, membuat cara-

cara untuk tes masuk sekolah tersebut. 2. Desain dilakukan dengan Tahap ini mentranslasi kebutuhan perangkat lunak dari tahap analisis kebutuhan perangkat lunak dijadikan sebagai dasar dalam desain. Desain yang dihasilkan pada tahap ini adalah Struktur Navigasi, Entity Relationship Diagram 
(ERD), Logical Record Structure (LRS), dan merancang pengujian menggunakan black box testing. 3. Pembuatan kode program ke dalam Bahasa pemrograman HTML, PHP dengan menggunakan MYSQL dan XAMPP. 4. Pengujian dilakukan dengan pengujian blackbox testing. 5. Pendukung atau pemeliharaan dilakukan dengan cara menganalisis spesifikasi untuk perubahan sistem yang sudah ada, tapi tidak untuk sistem baru. Teknik pengumpulan data yang digunakan dalam penelitian ini diantaranya: 1. Observasi secara langsung mengenai kegiatan operasional system perimaan peserta didik baru di beberapa sekolah wilayah Bekasi. 2. Studi pustaka dengan mengumpulkan buku-buku dan literatur artikel ilmiah yang berhubungan dengan permasalahan penelitian.

\section{HASIL DAN PEMBAHASAN}

\section{Activity Diagram Bussiness Process}

Activity Diagram Bussiness Process pada penelitian ini seperti pada Gambar 1.

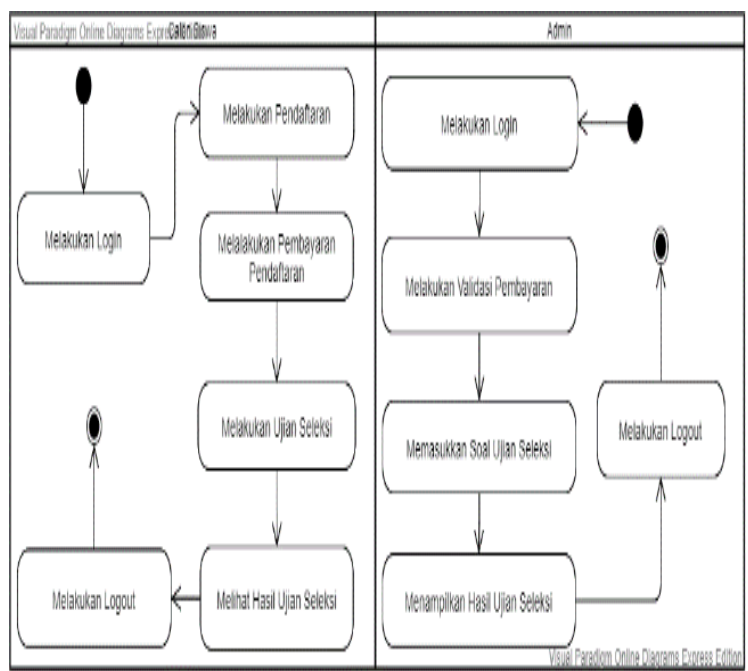

Sumber: Hasil Penelitian (2020)

Gambar 1. Acitivity Diagram Bussiness Process PPDB online dimasa Pandemi Covid-19

2. Use case Diagram

Use Case Diagram pada penelitian ini seperti pada Gambar 2.

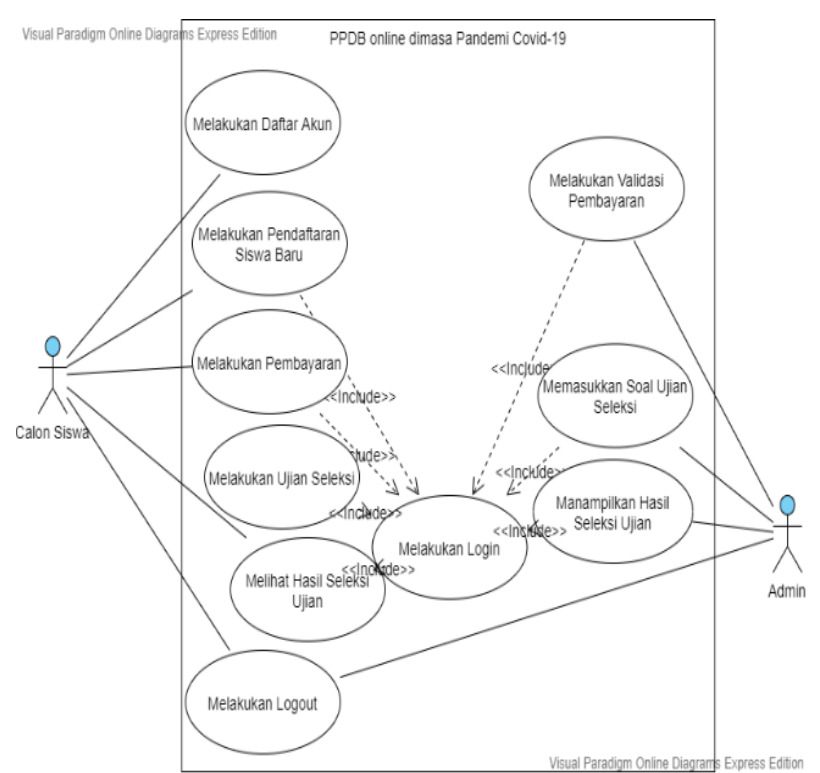

Sumber: Hasil Penelitian (2020)

Gambar 2. Use Case Diagram PPDB online dimasa Pandemi Covid-19

Tabel 1. Use case diagram alur Calon Siswa

\begin{tabular}{|c|c|}
\hline Use case & Calon siswa \\
\hline Actor & Calon siswa \\
\hline $\begin{array}{l}\text { Brief } \\
\text { Description }\end{array}$ & $\begin{array}{l}\text { Saat Calon siswa belum } \\
\text { memiliki akun maka tidak } \\
\text { dapat login ke dalam system } \\
\text { dan wajib melakukan Daftar } \\
\text { Akun. Jika Calon siswa } \\
\text { sudah memiliki akun maka } \\
\text { pengguna dapat melakukan } \\
\text { aktifitas sebagai berikut: } \\
\text { 1. Melakukan pendaftaran } \\
\quad \text { siswa baru } \\
\text { 2. Melakukan pembayaran } \\
\text { 3. Melakukan ujian seleksi } \\
\text { 4. Melihat hasil ujian seleksi } \\
\text { 5. Melakukan logout }\end{array}$ \\
\hline
\end{tabular}

\begin{tabular}{ll}
\hline $\begin{array}{l}\text { Alternative } \\
\text { Flow }\end{array}$ & $\begin{array}{l}\text { Jika pada saat login, } \\
\text { username dan password tidak } \\
\text { sesuai maka muncul kotak } \\
\text { peringatan dan Kembali } \\
\text { menuju halaman login }\end{array}$ \\
\hline Postcondition & $\begin{array}{l}\text { Jika semua atau sebagian } \\
\text { aktifitas telah dilakukan } \\
\text { maka dapat menggunakan } \\
\text { fitur logout untuk keluar dari } \\
\text { sistem }\end{array}$ \\
\hline
\end{tabular}

Sumber: Hasil Penelitian (2020) 


\section{Sequence Diagram}

Sequence Diagram pada penelitian ini seperti Gambar 3.

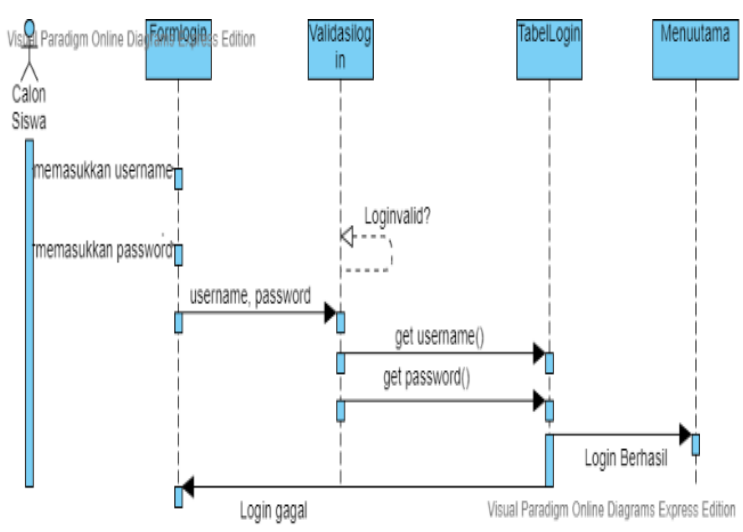

Sumber: Hasil Penelitian (2020)

Gambar 3. Sequence Diagram PPDB online dimasa pandemi Covid-19

\section{4. $E R D$}

Perancangan basis data pada PPDB secara daring dimasa pandemic covid-19 seperti pada Gambar 4.

5. Implementasi

a. Halaman menu utama Admin

Halaman menu utama admin berisi Data Pendaftaran, Pembayaran, Soal Ujian dan Pengumuman Ujian Seleksi dapat dilihat pada Gambar 5.

b. Halaman Data Pembayaran Halaman data pembayaran berisi pembayaran yang sudah masuk kemudian Admin melakukan validasi.

c. Halaman Soal Ujian Seleksi Ujian seleksi yang sudah dikerjakan oleh Calon siswa maka akan tampil pada halaman ini. Berikut tampilan pada Gambar 7.

d. Halaman Pengumuman Ujian Berikut hasil pengumuman ujian seleksi pada Gambar 8.

\section{KESIMPULAN} berikut:

Kesimpulan pada penelitian ini sebagai
1. Penerimaan peserta didik baru secara online menjadi solusi terbaik untuk dapat menerima siswa baru bagi sekolah dimasa pandemi Covid-19 ini.

2. Orang tua dan calon siswa akan mendapatkan informasi tentang penerimaan peserta didik baru dengan mudah cukup mengakses website dari rumah tidak perlu datang ke sekolah sehingga dapat menimbulkan kerumunan yang bisa meningkatkan penyebaran Covid-19.

3. Pembayaran pendaftaran menjadi lebih mudah dengan melakukan transfer via ATM.

\section{REFERENSI}

Abdulloh. (2018). 7 in 1 pemrograman web untuk pemula. PT Elex Media Komputindo.

Kusuma, M. H. (2016). Strategi Pemasaran Penerimaan Peserta Didik Baru Di SMK Muhammadiyah 2 Jatinom Klaten [Universitas Muhammadiyah Surakarta]. http://eprints.ums.ac.id/41849/

Madcoms. (2013). Tuntas Adobe Dreamweaver CS6 dengan Pemrograman PHP \& MySQL. CV.Andi Offset.

Muslih, M. T., \& Purnama, B. E. (2013). Pengembangan Aplikasi Sms Gateway Untuk Informasi Pendaftaran Peserta Didik Baru di SMAN 1 Jepara. Indonesian Journal of Network \& Security, 2, 50-55. https://doi.org/http://dx.doi.org/10.1123/ijns.v $2 \mathrm{i} 1.237$

PP. (2010). PERATURAN PEMERINTAH REPUBLIK INDONESIA NOMOR 17 TAHUN 2010.

https://jdih.kemenkeu.go.id/fullText/2010/17T AHUN2010PP.htm

Rerung. (2018). Pemrograman Web Dasar. Deepublish.

Subbeh, R. (2018, April 17). PPDB sebagai Tujuan Umum dan Khusus. Https://Www.Kompasiana.Com/. https://www.kompasiana.com/karyatulismulti/ 5ad5af03bde575680a596082/ppdb-sebagaitujuan-umum-dan-khusus

Supono, \& Putratama, V. (2016). Pemograman Web Dengan Menggunakan PHP dan Framework Codeigniter. Deepublish. 


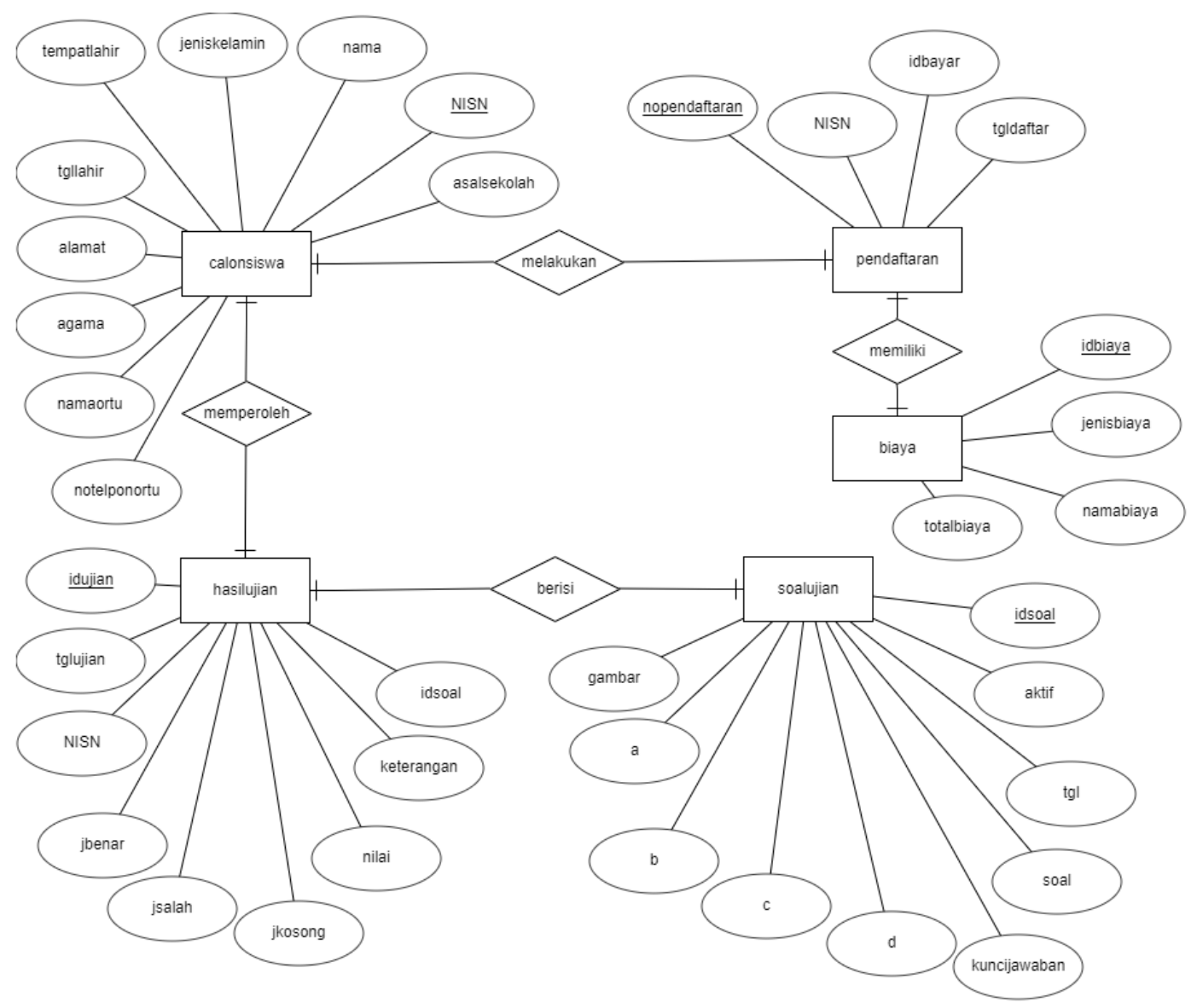

Sumber: Hasil Penelitian (2020)

Gambar 4. ERD PPDB online dimasa pandemi Covid-19

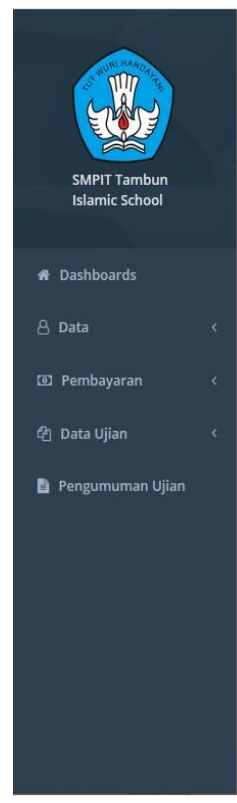

Sumber: Hasil Penelitian (2020)

Gambar 5. Halaman Menu Utama Admin PPDB secara online dimasa pandemi Covid-19 


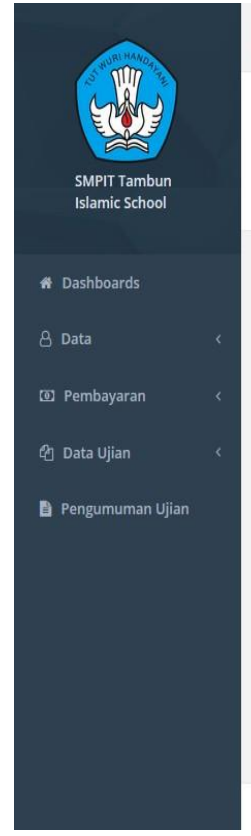

$\equiv$

Selamat Datang admin di SMPIT Tambun Islamic School.

Data Pembayaran Biaya

+ ADD Pembayaran

thDD PEMBaYARAN

Sumber: Hasil Penelitian (2020)

Gambar 6. Halaman Data Pembayaran PPDB secara online dimasa pandemi Covid-19
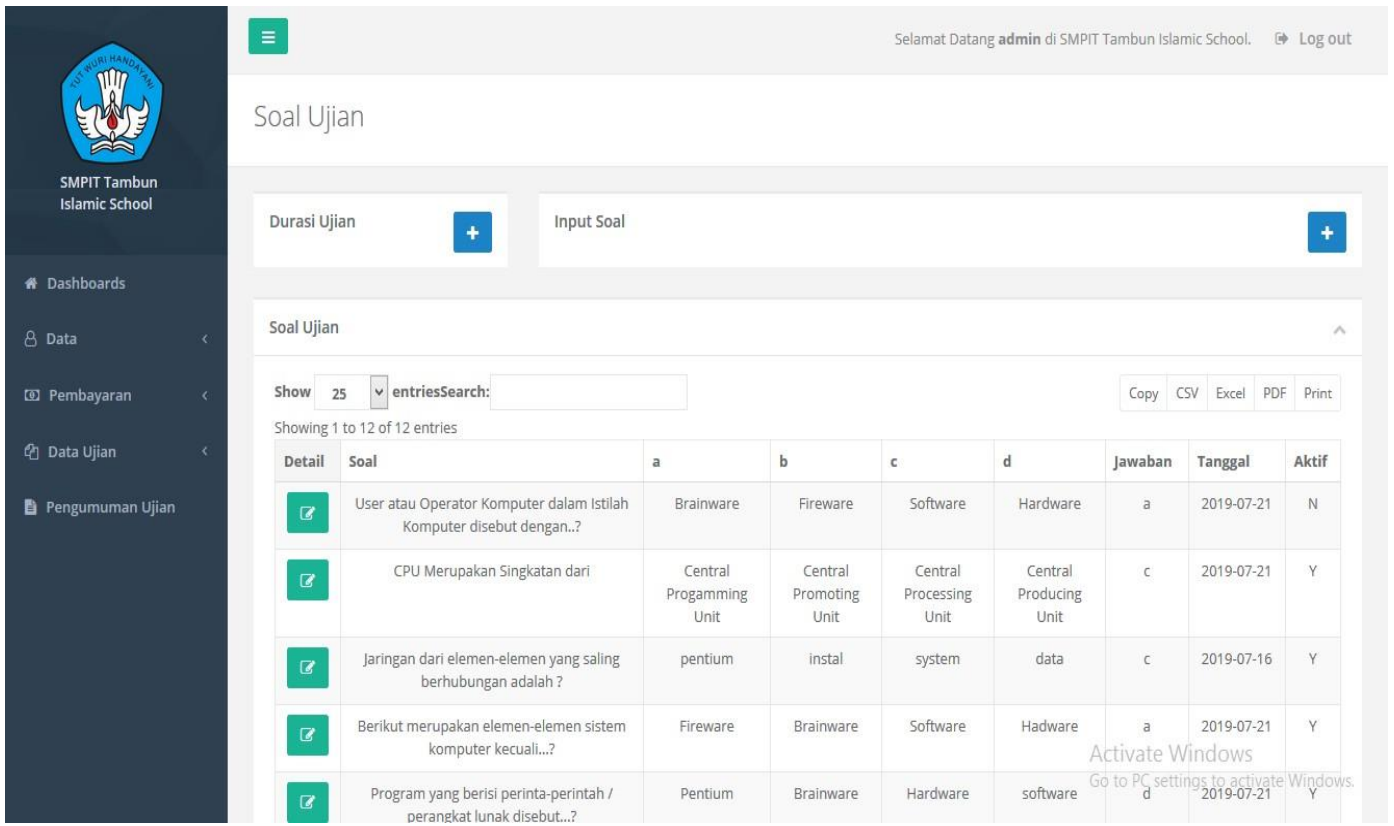

Sumber: Hasil Penelitian (2020)

Gambar 7. Halaman Soal Ujian Seleksi PPDB online dimasa pandemi Covid-19 


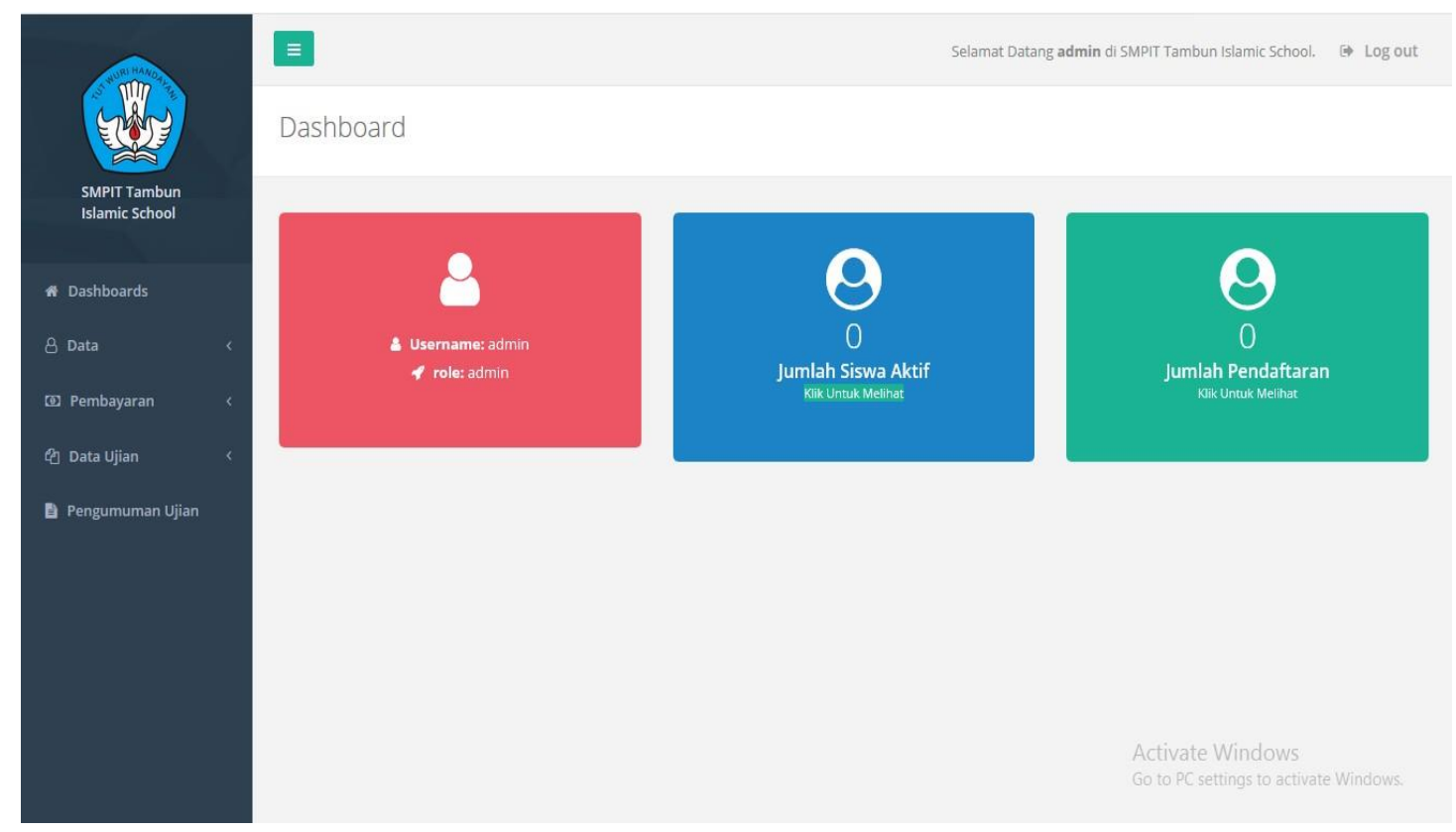

Sumber: Hasil Penelitian (2020)

Gambar 8. Halaman Hasil Ujian Seleksi PPDB secara online dimasa pandemi Covid-19 